\title{
Influence of Pesticide on Biochemical and Hematological Parameters in Beninese Vegetable Farmers
}

\author{
Prudence Agnandji \\ Etudiant, Unité de Biochimie et Biologie Moléculaire, Laboratoire de Biologie \\ Moléculaire et Environnement, Département de Biochimie et Biologie Cellulaire, \\ Université d'Abomey-Calavi 04BP0320 Cotonou, Bénin. \\ E-mail: a.prud05@gmail.com
}

\section{Lucie Ayi-Fanou (Corresponding author)}

Enseignante Chercheur, Unité de Biochimie et Biologie Moléculaire, Laboratoire de Biologie Moléculaire et Environnement, Département de Biochimie et Biologie Cellulaire, Université d'Abomey-Calavi 04BP0320 Cotonou, Bénin.

E-mail: afaluc@yahoo.fr

Boris Fresnel Cachon

Enseignant Chercheur, Faculté des Sciences et Techniques de Dassa-Zoume, Université des Sciences, Technologie, Ingénieurie et Mathémathiques, Dassa-Zoume, Bénin E-mail: cachonfreshly@gmail.com

Ingrid Sonya Mawussi Adjovi

Enseignante chercheur, Laboratoire de recherche sur l'Innovation Agricole, Faculté d'Agronomie de l' Université de Parakou, BP 123 Parakou (Rép. Bénin).

E-mail: samysonya@yahoo.fr

Laurel Omonlola Houéfa Ouidoh

Etudiante, Unité de Biochimie et Biologie Moléculaire, Laboratoire de Biologie 
Moléculaire et Environnement, Département de Biochimie et Biologie Cellulaire, Université d'Abomey-Calavi 04BP0320 Cotonou, Bénin.

E-mail: laurelouido@gmail.com

\begin{abstract}
Ambaliou Sanni
Enseignant Chercheur, Unité de Biochimie et Biologie Moléculaire, Laboratoire de Biologie Moléculaire et Environnement, Département de Biochimie et Biologie Cellulaire, Université d'Abomey-Calavi 04BP0320 Cotonou, Bénin.

E-mail: ambaliou.sanni@gmail.com
\end{abstract}

\title{
Fabrice Cazier
}

Directeur du Centre Commun de Mesures, Université du Littoral Côte d'Opale

Dunkerque, France. E-mail: fabrice.cazier@univ-littoral.fr

\author{
Received: January 12, 2018 Accepted: February 17, 2018 \\ doi:10.5296/jbls.v9i1.12461ＵRL: https://doi.org/10.5296/jbls.v9i1.12461
}

\begin{abstract}
In several countries, a lot of researches have shown the toxicity of pesticides on farmers. Meanwhile, few of them have dealt with vegetable farmers in Benin. Therefore, this study has been carried out to assess the effects of pesticides on vegetable farmers' health. This study is conducted on 30 vegetable farmers who used pesticides and 20 subjects as control group. Pesticides used by vegetable farmers and their risky behavior were investigated. Their blood samples were collected and some tests were performed for hematological and biochemical parameters. For the statistical analysis of the results, Student's test was used. Our investigations revealed that vegetable farmers of Benin were exposed to different active ingredients of pesticides such as (Abamectin, Acetamiprid, Chlorpyriphos ethyl, Cyfluthrin, Cypermethrin, Emamectin benzoat, Flubendiamid, Lambdacyhalothrin, Mancozeb, Profenofos, Spinosad and Spirotétramate). The hematological parameters showed significant decrease in White blood cell (WBC), Red blood cell (RBC), Hemoglobin (HGB), Hematocrit (HTC), Mean Corpuscular Volume (MCV), Platelet (PLT) count among study group. The enzymatic activities of Aspartate Aminotransferase (AST), Alanine Aminotransferase (ALT) have significantly raised between vegetable farmers and the control group, while the serum concentration in urea and creatinine showed insignificant difference in the study group. These
\end{abstract}


results suggest that pesticides have adverse effects on vegetable farmers of South of Benin.

Keywords: Pesticide, Vegetables farmers, Hematocrit, Aminotransferase, creatinine

\section{Introduction}

Benin like other African countries has known a demographic growth in these past few years. Then, Food security has become a major concern for all (Assogba-Komlan et al., 2007). Urban and suburban agriculture play an essential role in the struggle against food insecurity and poverty (FAO., 2013). Urban agriculture has socio-economic, environmental and health benefits (Zasada et al., 2011).

Despite these beneficial effects, vegetable farmers encounter several problems as crops and vegetable attack by pests (insect pests, microscopic fungus, nematodes, mites, etc.). These facts involve lower yields at harvest. In these conditions, vegetable farmers use pesticides to eliminate the pests. Pesticides significantly reduce pests and weeds, and then increase yields at harvest. In spite of pesticides beneficial effects, they have adverse impact on environment and health on subjects who are exposed. These effects are well documented and constitute a major problem that raises several questions.

In Pakistan, studies carried out on karachi farmers revealed the presence of pesticide residues in their bloods and the effects of those toxic molecules on vegetable farmer's health. Khan et al., (2008), reported these effects of pesticides residues on cholinesterase and phosphomonoesterase like that enzymes activities such as Aspartate Aminotransferase-AST, Alanine Aminotransferase-ALT, Alkaline phosphatase-ALP in the blood of exposed persons. Yaqub et al., (2014) reported in Nigeria, high prevalence of abnormal levels of cholinesterase in serum of the farmers.

Studies about pesticides sprayers shown oxidative stress inducing by pesticide could alter the detoxification mechanisms and scavenge enzymes (Khan et al., 2002). These toxic compounds disrupt cellular function and enzymes activities (Arafa et al., 2013). In human blood, pesticide residues can affect hematological parameters as white blood cell (WBC), Hemoglobin (HGB) and platelets (PLT) (Ismail et al., 2010). Another study revealed the influence of pesticides, particularly chlorinated hydrocarbons on various blood parameters (Dustan et al., 1996). Fujitani et al., (1997) shows a decrease in Red Blood Cell (RBC) and Platelet (PLT) count, Hemoglobin concentration (HGB), Mean Corpuscular Hemoglobin Concentration (MCHC) and percentage of Hematocrit (HCT) due to pesticide.

In Benin, few researches are about adverse effects of pesticides on vegetable farmers' health. It's in this context that we initiate this research to assess the toxic effects of pesticides on exposed subjects. Investigations were carried out about pesticides used, symptoms, blood, liver and kidney disorders. 


\section{Macrothink}

\section{Materials and Methods}

\subsection{Included and excluded criteria}

After investigation about pesticides used by vegetable farmers of Southern of Benin, 30 farmers and 20 control subjects were recruited.

\subsubsection{Target groups}

People included in this study are at least 18 years old and have given their consent. Farmers using pesticides on their farms are the exposed group and those who have no previous occupational exposure to pesticides or any other industrial chemicals are considered as the control group.

\subsubsection{Excluded groups:}

Peoples who have less than 18 years old, farmers who didn't give their consent, subjects who didn't use pesticides but lived side issue of vegetables farms, those suffering from different pathologies (diabetes, hypertension, renal failure, viral hepatitis); smokers and alcohol drinkers were also excluded in this study.

\subsection{Data collection}

The exposed group is invested of 30 vegetables farmers (21 males and 9 females from south of Benin, Cotonou and Seme-Kpodji) chronically exposed to pesticides. They had been using pesticides for an average of $9.6 \pm 7.5$ years. Individual data about pesticide exposure were investigated e.g the protective tools used and the hazard behavior of farmers. The symptoms relative to pesticide-exposition were recorded by interview.

As for the control group, it is consisted of 20 healthy individuals non farmers (13 males and 8 females) randomly chosen in the same commune and didn't expose to pesticides or any other industrial chemicals through a professional activity.

\subsection{Blood sampling}

Blood samples were taken on the farmers (during agricultural activity) and on control group before breakfast in dry and EDTA (Ethylene diamine tetra acetic Acid) tubes.

\subsubsection{Hematological investigation}

Blood sample collected in EDTA tube were used to measure hematological parameters e.g. $\mathrm{RBC}, \mathrm{WBC}$ and PTL count, HGB concentration, percentage of $\mathrm{HTC}, \mathrm{MCHC}, \mathrm{MCH}$ and MVC were assessed using Counter BC-2800 Auto Hematological Analyzer

\subsubsection{Biochemical investigation}

Blood sample collected in dry tube was centrifuged at $3000 \mathrm{rpm}$ during 15 minutes and serum sample was used for biochemical tests. The tests were performed by using UV-visible Spectrophotometer CYAN ${ }^{\text {Plus }}$.

Liver function was determinate in serum transaminses (AST-ALT) and serum Gama 


\section{Macrothink}

Glutammyl transferase (GGT) by kinetic method as recommended by the International Federation of Clinical Chemistry (IFCC). The diagnostic kits Biolabo REF 80025, REF 80027 and 8110 were used to perform all the tests.

Kidney function was measured in serum creatinine $(\mathrm{mg} / \mathrm{L})$ and urea $(\mathrm{g} / \mathrm{L})$ level according to kinetic and colorimetric methods. All the tests have been carried out with diagnostic kits Biolabo REF 80107 and REF 80221 available in stores.

\subsection{Statistical analysis}

The biochemical and hematological data were represented in average \pm standard deviation. Statistical analysis was performed using SigmaPlot Statistical Analysis Sofware 2001 version 10.0. The distribution and difference of biochemical and hematological parameters between vegetables farmers and control group were statistically tested by Student test. The statistical significance for each analysis was considered at $\mathrm{P}<0.05$.

\subsection{Ethic consideration}

The proposal of this work was reviewed and agreed by the Research Ethics Board of the Applied Biomedical Sciences Institute. All participants signed a consent after information on protocol prior to enroll in the study.

\section{Results}

\subsection{Actives ingredients of pesticides used by the farmers}

Pesticides that are commonly utilized by the farmers during this study are listed in Table 1 (using their common name and World Health Organization classification). From this table, it can be seen that farmers used more frequently some pesticides which active ingredients are lambdacyhalothrin, acetamiprid, profenofos, spinosad and then they were exposed to them.

Table 1. Pesticides utilized by famers

\begin{tabular}{llll}
\hline $\begin{array}{l}\text { Chemical } \\
\text { classification }\end{array}$ & \multicolumn{1}{c}{ Ordinary name } & \multicolumn{1}{c}{$\begin{array}{c}\text { WHO } \\
\text { Classification }\end{array}$} & $\begin{array}{c}\text { \% of pesticides } \\
\text { used }\end{array}$ \\
\hline Amermectin & Abamectin & II & 3.8 \\
Emmamectin benzoat & II & III & 1.1 \\
Carbamate & Mancozeb & II & 3.3 \\
Spinosyns & Spinosad A/Spinosad & II & 16.9 \\
& D & II & 31.7 \\
Pyrethroid & Lambda cyhalothrin & II & 3.8 \\
& Cypermethrin & III & 3.8 \\
Neonicotinoid & Cypermethrin & II & 14.2 \\
Ketoenol & Acetamiprid & III & 3.3 \\
Diamid & Spirotetramat & III & 3.3
\end{tabular}




\section{Organophosphorus}

Profenofos

II

10.9

Chlorpyriphos ethyl

II

3.8

\subsection{Protectives tools for farmers and their behavior risky}

To avoid direct exposure to pesticides which have toxic properties, various protective tools are used by the famers. $29.5 \%$ of vegetable farmers don't protect themselves against pesticides. The other ones use various protective tools as indicated in Table 2. Water is important in vegetable farm and then, different springs are used by farmers to water their vegetables. Among the farmers who have at one's disposal some drillings, less than $37.5 \%$ of the farmers consume this water, as indicated in Table 2.

Table 2. Hazards attitude

\begin{tabular}{ll}
\hline Variable & Frequency \% \\
\hline Protection tools & 0 \\
Mask & 34.7 \\
Glove & 27.4 \\
Scarf & 6.3 \\
Boot & 0 \\
Waterproof & 2.1 \\
Goggles & 29.5 \\
Don't protect himself & \\
Other use spring for watering & 37.5 \\
Consumption & 62.5 \\
Don't use & \\
\hline
\end{tabular}

3.2 Symptoms felled by farmers after spraying

After use of pesticides, different symptoms were cited by the farmers such as pricking sensation, watering, dizziness, vomiting, sexual weakness, hypersalivation, nausea, abdominal cramp, muscular weakness as indicated in Fig 1. 


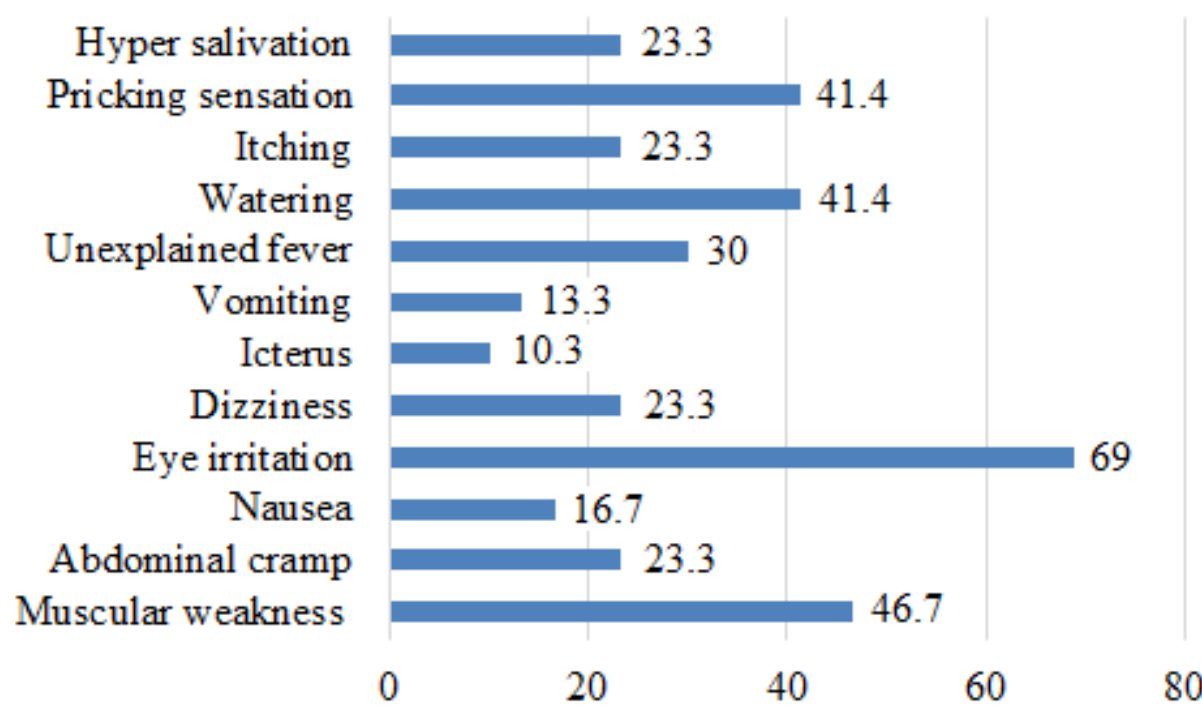

Figure 1. Symptoms developed by farmers after spraying

\subsection{Variation of Hematological parameters}

Chronic exposure to mixture of pesticides can affect farmer's health.

Hematological parameters measured in the study groups are presented in Table 3. According to these results, WBC, RBC, HGB, HTC, MVC and PLT values are significantly lower in farmers compared with controls, whereas WBC, RBC, HGB, HTC, MVC and PLT values are significantly higher. For $\mathrm{MCHC}$ and $\mathrm{MCH}$, there isn't significant variation in the group.

Tableau 3. Hematological profile for farmers and control groups

\begin{tabular}{llll}
\hline & $\begin{array}{l}\text { Exposed farmers } \\
(\mathrm{n}=30)\end{array}$ & Control $(\mathrm{n}=20)$ & \\
\hline Parameters & Mean \pm SD & Mean \pm SD & p-Values \\
WBC count $\left(10^{3} / \mathrm{mm}^{3}\right)$ & $4.347 \pm 0.7785$ & $5.400 \pm 0.8227$ & $0.001^{* * *}$ \\
RBC count $\left(10^{6} / \mathrm{mm}^{3}\right)$ & $4.8953 \pm 0.66402$ & $5.4900 \pm 0.51859$ & $0.001^{* * *}$ \\
HGB $(\mathrm{g} / \mathrm{dL})$ & $13.490 \pm 1.8854$ & $15.365 \pm 1.8420$ & $0.001^{* * *}$ \\
HTC $(\%)$ & $42.200 \pm 5.8392$ & $45.850 \pm 5.1327$ & $0.028^{*}$ \\
MCV $(\mathrm{Fl})$ & $88.333 \pm 7.5901$ & $83.650 \pm 4.0429$ & $0.015^{*}$ \\
MCH $(\mathrm{pg})$ & $27.600 \pm 2.6077$ & $27.550 \pm 1.6694$ & 0.940 \\
MCHC $(\mathrm{g} / \mathrm{dL})$ & $32.033 \pm 2.3851$ & $32.950 \pm 1.1910$ & 0.119 \\
PLT count $\left(10^{3} / \mathrm{mm}^{3}\right)$ & $184.167 \pm 56.2256$ & $251.800 \pm 35.3890$ & $0.001^{* * *}$ \\
\hline
\end{tabular}

$* * * p<0.001:$ Highly significant $; * p<0.05$ : Significant 
3.3 Determination of AST, ALT, GGT activity and Urea-Creatinine level in study groups serum

The figure 2 presents variation of biochemical parameters determined in vegetable farmers and control group. Significant difference is observed in exposed and control groups for serum enzymes as AST, ALT, $(\mathrm{P}<0.001),(\mathrm{P}<0.05)$. On the other hand, there is no significant difference in the variation of the GGT, urea and creatinine.

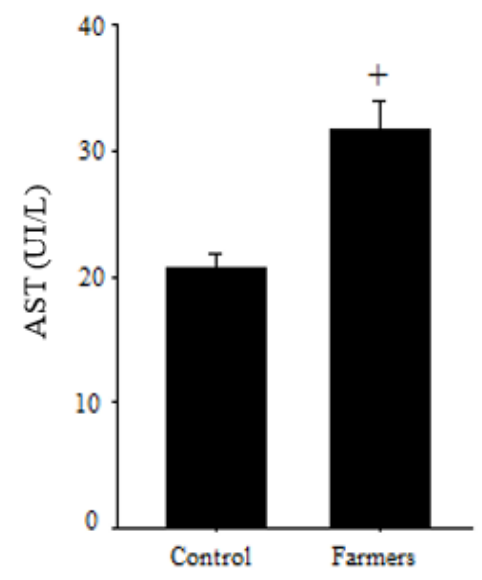

A $p<0,001$

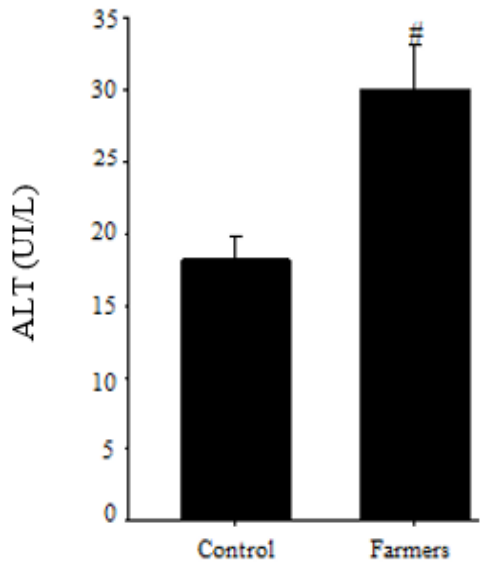

B $p<0,05$

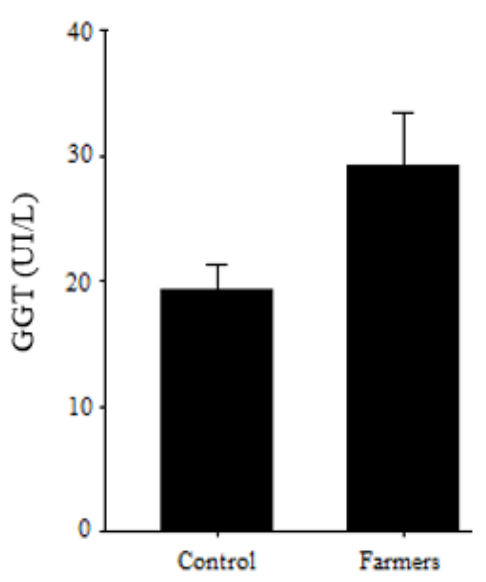

C $p>0,05$

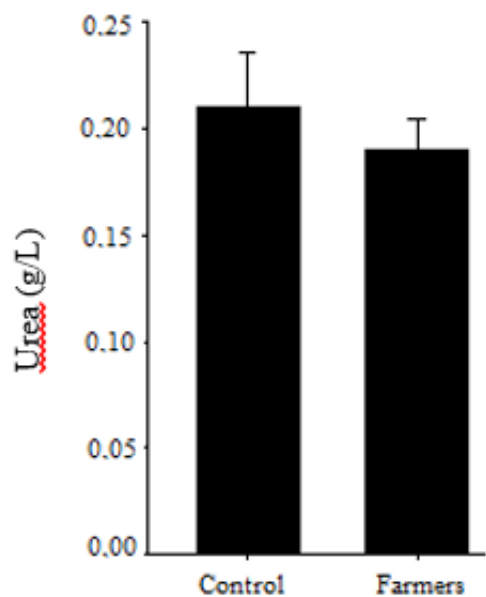

D $p>0,05$

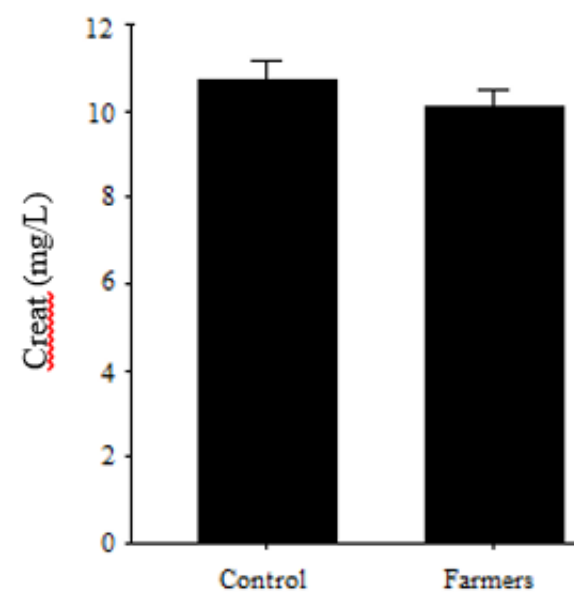

$\mathbf{E} \quad p>0,05$

Figure 2. A: AST activity in vegetable farmers and control; B: ALT activity in vegetable farmers and control; C: GGT activity in vegetable farmers and control; D: Blood urea levels in vegetable farmer and control; E: Blood creatinine levels in vegetable farmer and control.

\section{Discussion}

In recent years, vegetable farming has undergone considerable increase in developing countries like Benin (Pazou et al., 2010). Our research on vegetable farmers shows that

they are predominantly men. That may be explained by the fact that this activity requires physical power. To control pests which contribute significantly to yield loss, vegetable famers 
use different pesticides (Adje et al, 2009). Active ingredients of pesticides used by vegetable farmers belong to groups of insecticides and fungicides. The most used in south of Benin are insecticides. Our results are consistent with those of Afari-Sefa et al., (2015) who found that insecticides are most used by vegetable farmers of Ghana. This supports the general perception of farmers who chosen pesticides to control pests. In the same way, farmers like to satisfy consumers by producing high yields which need high proportions of fungicides and insecticides (Thomas., 2003). The active ingredients of pesticides cited by farmers are Hazard category II and III of World Health Organization (WHO). They are moderately and slightly hazardous but this constitutes a chronic exposition which can affect the farmer's health in long term. In view of these observations, preventive action is needed to protect public health from intoxication and environment from pollution.

According to good agricultural practice, the use of pesticides requires total protection to prevent the farmers to pesticide contamination. After our investigation, it appears that farmers are not sufficiently informed about the importance of protection tools. None of the farmers uses full protection. Nevertheless, some of them use scarf, gloves and boots. Only $2.1 \%$ of farmers use eyeglasses to protect their eyes during vegetable treatments. On the other hand, $29.5 \%$ of the farmers don't use any protective tools. Farmers who don't protect themselves during vegetable treatments are exposed directly to pesticides through various routes including dermal, nose and eyes (Kim et al., 2017). In addition, it was found that some of the farmers use the spring of the farm's water for domestic use. Consequently, they are indirectly exposed to pesticides through the mouth (Lim et al., 2009; Albouy-Llaty et al., 2016).

Pesticides are "poisons by design" and the chemical contaminations resulting from their unsafe use are the most prevalent and serious occupational hazards to agricultural workers in developing countries. Organophosphorus pesticides (OP) and pyrethroids (PYR) are among the main chemicals widely used worldwide to control agricultural pests.. The farmers, after spraying pesticides without complete protective equipment, complain for different symptoms such as pricking sensation, itching, hypersalivation, watering, vomiting, eye irritation, nausea, abdominal cramp and muscular weakness. These finding corroborate with those studies on management of acute pesticide (Guloglu et al., 2005; Michael et al., 2008; Ssemugabo et al., 2017).

Diagnosis of adverse effects of pesticides is confirmed by laboratory exam. In our study, Hematological parameters (WBC, RBC HGB, HTC, MCV and PLT) analyzed showed significant decrease except $\mathrm{MCH}$ and $\mathrm{MCHC}$ parameters between pesticide-exposed and control groups. Gaikawad et al (2015), found significant differences decrease of WBC count between farmers and control groups. Parron et al (1996) and Jyotsana et al (2003), also obtained similar results. Patil et al., (2009) and Rastogi et al., (2008) found significant decrease of hematological parameters as HGB, HCT, MVC and RBC. Pesticides are a toxic compound which can inhibit biosynthesis steps of the heme (Patil et al., 2003). That is why pesticides residues caused reduction of cell blood count and induced anemia caused

by inhibition of HGB biosynthesis and reducing the lifespan of red cells. 
About MCH and MCHC, our results are in contrary with those of Sudjaroen et al., (2017). They found that $\mathrm{MCH}$ and $\mathrm{MCHC}$ concentration values of non-organic farmers were lower than reference range and interpreted as anemia. Our finding suggest that pesticides residues can reduce the size of the RBC without a decrease of HCB contained in the RBC.

As for the analysis of serum enzymes (ALT, AST, GGT) which reflect hepatic damages, we found significantly higher activity of AST and ALT except GGT between farmers compared to control group. Arafa et al., (2013), reported an increasing of AST and ALT activities in the serum of Egyptian farmers who were exposed to pesticides compare to a control group. The similar results were found by Altuntas et al., (2002) and Around et al., (2012). The elevation of the aminotransferases activities in blood has been considered as an indicator of tissue damage. Residues of pesticides can impair hepatocellular which can release greater intracellular enzymes into the blood than normal levels.

In this study, serum urea and creatinine levels were statistical insignificant in study groups. Our results corroborate with those of Arafa et al., (2013), who observed no significant elevation of serum urea and creatinine levels among sprayers of pesticides. Contrary to our study, previous study on covered workers of chemical products producing dust pesticides, reported minimal nephrotoxic changes in these workers with increasing levels of serum creatinine and urea. High levels of urea and creatinine were observed in the serum of workers who are exposed to pesticides Dilshad et al., (2008). This levels were interpreted by a subtle nephrotoxic changes (Hernandez et al., 2006).

\section{Conclusion}

Extensive application of pesticides is a common practice around the world. In Benin, different pesticides are used for vegetable treatments. Lambda cyhalothrin is active ingredient contained in many pesticides used in Benin. Those pesticides are toxic substances which are harmful to humans. The most common symptoms developed by vegetable farmers are eye irritation, pricking sensation, watering, muscular weakness, etc. But their use without protective equipment have adverse effects on hematological cells (WBC, RBC, HGB, HTC, MVC and PLT) and liver (increasing activity of AST and ALT) of the vegetables farmers

\section{Acknowledgement}

We are grateful to farmer group who cultivate vegetables in commune of Cotonou and Seme-kpodji and all the people who belongs to the control group. We would like also to thank the Director of Deo-Gratias laboratory who accepts to collaborate with us.

\section{References}

Adje, K., Djidji, A. H., Fondio, L., N’zi, J. C., \& Kouame, C. (2009). Efficacité des traitements phytosanitaires contre les ravageurs et maladies de quatre variétés de tomate au centre de la Côte D’ivoire. Agronomie Africaine 21 (2), 165-172

Afari-Sefa, V., Asare-Bediako, E., Kenyon, L., \& Micah, J. A. (2015). Pesticide use practices and perceptions of vegetable farmers in the cocoa belts of the Ashanti and Western Regions of Ghana. Advances in Crop Science and Technology, 3, 174 
Albouy-Llaty, M., Limousi, F., Carles, C., Dupuis, A., Rabouan, S., \& Migeot, V. (2016). Association between exposure to endocrine disruptors in drinking water and preterm birth,

taking neighborhood deprivation into account: a historic cohort study. Int J Environ Res Public Health. 13(8). https://doi.org/10.3390/ijerph13080796

Altuntas, I., Delibas, N., Demirci, M., Kilinc, I., \& Tamer, N. (2002). The effects of methidathion on lipid peroxidation and some liver enzymes: role of vitamin E and C. Arch Toxicol, 76, 470-473. https://doi.org/10.1007/s00204-002-0359-1

Arafa, A., Afify, M., \& Samy, N. (2013). Evaluation of adverse health effects of pesticides exposure biochemical \& hormonal among Egyptian farmers. J Appl Sci Res. 9(7), 4404-9

Araoud, M., Neffeti, F., Douki, W., Hfaiedh, H. B., Akrout, M., Hassine, M., Najjar, M. F., \& Kenani, A. (2012). Adverse effects of pesticides on biochemical and haematological parameters in Tunisian agricultural workers. Journal of Exposure Science and Environmental Epidemiology, 22, 243-247. https://doi.org/10.1038/jes.2012.11

Assogba-Komlan, F., Anihouvi, P., Achigan, E., Sikirou, R., Boko, A., Adje, C., Ahle, V., Vodouhe, R., \& Assa, A. (2007). Pratiques Culturales et Teneur en Eléments Antinutritionnels (Nitrates et pesticides) du Solanum macrocarpon au Sud du Bénin. Africain Journal of Food, Agriculture, Nutrition and Development, 7, 1-21

Dilshad, A. K., Mahwish, M. B., Farooq, A. K., Syed T. N., \& Karam, A. (2008). Adverse Effects of Pesticides Residues on Biochemical Markers in Pakistani Tobacco Farmers. Int J. Clin. Exp. Med, 1, 274-282

Dunstan, R. H., Roberts, T. K., Donohoe, M., McGregor, N. R., Hope, D., Taylor, W. G., Wathins, J. A., Murdoch, R. N., \& Butt, H. L. (1996). Bioaccumulated chlorinated hydrocarbons and red/white blood cell parameters. Biochemical and Molecular Medicine, 58, 77-84. https://doi.org/10.1006/bmme.1996.0035

FAO, «Agriculture urbaine et sécurité alimentaire,» Food and Agriculture Organization. 2013 Oct ; http://www.fao.org/newsroom.

Fujitani, T., Tada, Y., Noguchi, A.T., Yoneyama, M. (1997). Hematoxicity of chloroform (CIPC) in F344 rats. Toxycology, 123, 111-124.

Gaikwad, A. S., Karunamoorthy, P., Kondhalkar, S. J., Ambikapathy, M., \& Beerappa. R. (2015). Assessment of hematological, biochemical effects and genotoxicity among pesticide sprayers in grape garden. Journal of Occupational Medicine and Toxicology. 10, 11

Guloglu, C., \& Kara, I. H. (2005). Acute poisoning cases admitted to a university hospital emergency department in Diyarbakir, Turkey. Hum Exp Toxicol, 24, 49-54. https://doi.org/10.1191/0960327105ht499oa

Hernandez, F. A., Gomez, M. A., Perez, V. G., Lario, V. J., Pena, G., \& Gill, F. (2006). Influence of exposure to pesticides on serum components and enzyme activities of cytotoxicity among intensive agricultural farmers. Environ. Res, 102, 70-76. 
https://doi.org/10.1016/j.envres.2006.03.002

Ismail, A. A., Rohlman D. S., Abdel, R. G. M., Abou, S. M. E., \& Hendy, O. M. (2010). Clinical and Biochemical Parameters of children and Adolescents Applying Pesticides. The International Journal of Occupational and Environmental Medicine, 1-3

Jyotsana, A. P., Arun, J. P., Sanjay, \& P. G. (2003). Biochemical effects of various on sprayers of grape gardens. Indian Journal of ClinicalBochemistry, 16-22.

Khan, D. A., Bhatti M. M., Khan F. A., \& Naqvi, S. T. (2002) Evaluation of pesticides induced toxicity by oxidative stress and inflamatory biomarker. Pakistan Armed Forces Medical Journal, 58, 380-6

Khan, D.A., Bhatti, M.M., Khan, F.A., Naqvi, S.T., and Karam, A. (2008). Adverse effects of pesticides residues on biochemical markers in Pakistani tobacco farmers. Int J Clin Exp Med 2008: 1, 274--282.

Kim, K. H., Kabir, E., \& Jahan, S. A. (2017). Exposure to pesticides and the associated human health effects. Science of the Total Environment, 575, 525-35. https://doi.org/10.1016/j.scitotenv.2016.09.009

Lim, S., Ahn, S. Y., Song, I. C., Chung, M. H., Jang, H. C., Park, K. S., Lee, K. U., Pak, Y. K., \& Lee, H. K. (2009). Chronic exposure to the herbicide, atrazine, causes mitochondrial dysfunction and insulin resistance. PLoS One, 4, 4. https://doi.org/10.1371/journal.pone.0005186

Michael, E., Nick, A.B., Peter, E., Andrew, H. D. (2008) Management of acute organophosphorus pesticide poisoning, review

Parrón, T., Hernández, A. F., Pla, A., \& Villanueva, E. (1996). Clinical and biochemical changes in greenhouse sprayers chronically exposed to pesticides. Hum Exp Toxicol, 15, 957-63. https://doi.org/10.1177/096032719601501203

Patil, A. J., \& Govindwar, S. P. (2003). Biochemical effects of various pesticides on sprayers of grape gardens. Ind. J. Clin. Biochem., 18, 16-22. https://doi.org/10.1007/BF02867362

Patil, J. A., Patil, A. J., Sontakke, A. V., \& Govindwar, S. P. (2009). Oxidative stress and antioxidants status of occupational pesticides exposed sprayers of grape gardens of western Maharashtra (India). J Environ Health Res, 9, 81-89

Pazou, Y. E. A., Soton, A., Azocli, A., Acakpo, H., Boko, M., Fourn, L., Houinsa, D., Keke J. C., \& Fayomi, B. (2010). Contamination du sol, de l'eau et des produits maraîchers par des substances toxiques et des métaux lourds sur le site de Houéyiho (Cotonou) en République du Bénin. Int. J. Biol. Chem. Sci, 4(6), 2160-2168

Rastogi, S. K., Singh, V. K., Jyoti, C. K., Siddiqui, M. K. J., Mathur, N., \& Bharti, R. S. (2008). Monitoring of plasma butyrylcholinesterase activity and hematological parameters in pesticide sprayers. Indian Journal of Occupational and Environmental Medicine, 12(1), 29-32. https://doi.org/10.4103/0019-5278.40813 
Ssemugabo, C., Abdullah, A. H., Neebye, R. M., Nabankema, V. M. M. K., Ssekimpi, D., \& Erik, J. (2017). Prevalence, Circumstances, and Management of Acute Pesticide Poisoning in Hospitals in Kampala City, Uganda. Environmental Health Insights, 11, 1-8

Sudjaroen, Y., \& Suwannahong, K. (2017). Comparison of Biochemical, Hematological

Parameters and Pesticide Expose-related Symptoms among Organic and Non-Organic Farmers, Singburi, Thailand. Asian Journal of Pharmaceutics. 11 (1), S235

Thomas, M. R. (2003). Pesticide usage in some vegetable crops in Great Britain: real on-farm applications. Pest Management Science, 59, 591-596. https://doi.org/10.1002/ps.716

Yaqub, S. A., Rahamon, S. K., \& Arinola O. G. (2014). Haematological and Immunological Indices in Nigerian Farmworkers Occupationally Exposed to Organophosphate Pesticides. Eur J Gen Med, 11(2), 109-114

Zasada, I. (2011). Multifunctional peri-urban agriculture-A review of societal demands and the provision of goods and services by farming. Elsiver Land Use Policy, 28, 639-648.

https://doi.org/10.1016/j.landusepol.2011.01.008

\section{Copyright Disclaimer}

Copyright for this article is retained by the author(s), with first publication rights granted to the journal.

This is an open-access article distributed under the terms and conditions of the Creative Commons Attribution license (http://creativecommons.org/licenses/by/3.0/). 